\title{
ANALISIS SISTEM INFORMASI PENJADWALAN UNIVERSITAS ‘AISYIYAH YOGYAKARTA
}

\author{
Zahra Arwananing Tyas \\ Program Studi Teknologi Informasi, Fakultas Sains dan Teknologi, Universitas 'Aisyiyah Yogyakarta \\ Jl. Siliwangi (Ring Road Barat) No. 63 Mlangi, Nogotirto, Gamping, Sleman, Yogyakarta. 55292 \\ Email:zahraatyas@unisayogya.ac.id
}

\begin{abstract}
Abstrak
Universitas 'Aisyiyah (UNISA) Yogyakarta sebelumnya merupakan STIKES 'Aisyiyah Yogyakarta, kini memiliki 2 fakultas baru selain fakultas ilmu kesehatan (FIKes) yaitu fakultas sains dan teknologi (FST) dan fakultas ekonomi, ilmu sosial dan humaniora (FEISHum). Bertambahnya fakultas dan program studi juga mengakibatkan bertambah pula jadwal perkuliahan dan jumlah mahasiswa. Perkuliahan yang berjalan di UNISA memiliki 2 jenis kurikulum, berbasis Blok dan Semester. Sistem penjadwalan yang ada di UNISA sudah dapat menangani masalah sistem blok maupun semester, hanya saja masih dilakukan dengan cara manual dengan ms. Excel pada bagian akademik sehingga dibutuhkan sistem penjadwalan otomatis yang bisa melakukan penjadwalan sesuai dengan kriteria, bobot dan syarat yang ada. Sebelum dilakukan penjadwalan otomatis, dibutuhkan analisis mendalam terhadap sistem yang sudah berjalan terhadap sistem informasi penjadwalan yang sudah ada. Metode analisis yang digunakan adalah Object Oriented Analysis and Desaign (OOAD) dengan beberapa diagram seperti usecase diagram, class diagram, squance diagram dan Entity Relational Diagram (ERD). Hasil dari Analisis sistem informasi penjadwalan ini akan terdokumentasi yang nantinya akan digunakan sebagai pedoman untuk tahap selanjutnya.
\end{abstract}

Kata kunci: Sistem Informasi Penjadwalan, Analisis Sistem, Object Oriented Analysis and Desaign (OOAD)

\begin{abstract}
Universitas 'Aisyiyah (UNISA) Yogyakarta was previously a STIKES' Aisyiyah Yogyakarta, now has 2 new faculties in addition to the health science faculty (FIKes) namely the science and technology faculty (FST) and the faculties of economics, social sciences and humanities (FEISHUm). The increase in faculties and study programs also resulted in increased lecture schedules and the number of students. Lectures that run at UNISA have 2 types of curriculum, Block and Semester based. The scheduling system at UNISA can handle block and semester system problems, it's just still done manually with ms. Excel in academic section so that an automatic scheduling system is needed to schedule according to criteria, weights and conditions. Before automatic scheduling is carried out, it takes an in-depth analysis of the system that is already running on existing scheduling information system. The analytical method used is Object Oriented Analysis and Desaign (OOAD) with several diagrams such as usecase diagrams, class diagrams, squance diagrams and Entity Relational Diagrams (ERD). The results of the analysis of this scheduling information system will be documented which will later be used as a guideline for the next stage.
\end{abstract}

\section{Keywords : Sistem Informasi Penjadwalan, Analisis Sistem, Object Oriented Analysis and Desaign (OOAD)}

\section{PENDAHULUAN}

Universitas 'Aisyiyah (UNISA) Yogyakarta merupakan perguruan tinggi swasta hasil pengembangan atau peningkatan status dari sekolah tinggi yang bernama STIKES 'Aisyiyah Yogyakarta. Perubahan yang terjadi juga membawa perubahan pada jumlah fakultas dan program studi yang ada. Saat masih STIKES hanya memiliki satu fakultas yaitu fakultas ilmu kesehatan (FIKes) dan hanya memiliki program studi yang berbasis kesehatan seperti kebidanan, keperawatan dan fisioterapi. Namun dengan berubahnya status menjadi Universitas kini UNISA memiliki tambahan 2 fakultas, yaitu fakultas sains dan teknologi (FST) dan fakultas ekonomi, ilmu sosial dan humaniora (FEISHum) dengan tambahan program studi seperti arsitektur, bioteknologi, teknologi informasi, akuntansi, managemen, komunikasi, psikologi, administrasi publik. Bertambah fakultas dan bertambah program studi juga pasti bersamaan dengan bertambahnya jadwal perkuliahan dan jumlah mahasiswa. Perkuliahan yang berjalan di UNISA memiliki 2 jenis kurikulum, berbasis Blok dan Semester. Program studi fisioterapi, teknologi laboratorium medis dan teknik 
radiodiagnostik dan radioterapi menggunakan sistem Blok dan program studi lain menggunaan sistem semester. Sistem Blok penyelenggaraan kuliahnya dari kuliah teori, tutorial, skill lab dan praktikum sedangkan sistem semester hanya kuliah teori dan praktikum. Perbedaan sistem yang digunakan dalam lingkungan kampus UNISA menjadi salah satu masalah yang harus diperhatikan karena penjadwalan pasti akan sedikit lebih membutuhkan tenaga dan pikiran.

Sistem penjadwalan yang ada di UNISA sudah dapat menangani masalah sistem blok maupun semester, hanya saja masih dilakukan dengan cara manual dengan ms. Excel pada bagian akademik. Sehingga dibutuhkan sistem penjadwalan yang bisa melakukan penjadwalan sesuai dengan kriteria, bobot dan syarat yang ada. Penjadwalan otomatis banyak menggunakan metode algoritma genetika karena optimasi yang baik. Kemudian saat jadwal sudah berjalan muncul kembali masalah saat ada jadwal pengganti yang membutuhkan ruangan untuk proses belajar, bagian akademik tidak mengetahui keadaan ruang ter-update saat itu. Selain jadwal pengganti, jadwal yang tertunda juga seharusnya dapat dimanfaatkan ruangannya untuk dipakai jadwal pengganti lainnya. Namun keadaan seperti itu tidak diketahui oleh bagian akademik, sehingga ruangan kosong yang seharusnya bisa dipakai jadwal pengganti hilang kesempatan karena tidak mengetahui bahwa ruangan tersebut kosong. Setelah jadwal kegiatan belajar mengajar itu berjalan sebaiknya kegunaan ruangan diperhatikan dengan seksama karena efisiensi dan efektifitas penggunaan ruang di UNISA ini harus dimaksimalkan. Permasalahan yang sering terjadi permohonan ruang untuk kuliah tambahan atau pengganti kepada akademik, didalam catatan akademik tidak ada ruangan kosong, padahal ada ruang kosong yang tidak digunakan sesuai jadwal karena dosen yang mengajar sedang ada acara sehingga tidak bisa memberikan perkuliahan. Ruang kosong yang dijadwalkan tadi tidak dipergunakan namun bagian akademi tidak mengetahuinya. Oleh sebab itu, peneliti tertarik untuk menganalisis untuk sistem informasi ruang dan jadwal yang dapat menyelesaikan permasalahan agar penggunaan ruangan kuliah dapat efektif dan efisien. Dengan adanya Sistem Informasi Ruang dan Jadwal ini akan sangat bermanfaat untuk bagian akademik dalam melakukan manajemen penggunaan ruang dan pembentukan jadwal untuk 18 program studi yang ada di Universitas 'Aisyiyah Yogyakarta. Sebelum dibuatnya Sistem Informasi Ruang dan Jadwal dengan penjadwalan otomatis, perlu dilakukan analisa terhadap Sistem Informasi Ruang dan Jadwal yang sudah ada terlebih dahulu. Dalam penelitian ini akan dilakukan analisis Sistem Informasi Ruang dan Jadwal menggunakan metode Object Oriented Analysis and Design (OOAD).

\section{DASAR TEORI}

Unified Process merupakan salah satu software development process yang telah mendukung konsep berorientasi objek. Unified Process mempunyai tiga karakteristik utama, yaitu [1]) :

\section{a. Use Case Driven}

Use case tidak hanya merupakan tool untuk menspesifikasi kebutuhan fungsional sistem, tetapi use case juga mengarahkan semua workflow dalam proses pengembangan software. Model design dan implementasi yang merealisasikan use case serta sejumlah test case untuk pengujian dibuat berdasarkan use case model.

\section{b. Architecture Centric}

Arsitektur merupakan pandangan terhadap keseluruhan design yang menonjolkan karakteristikkarakteristik yang penting dan meninggalkan sisi detail-nya. Arsitektur dan use case haruslah seimbang. Realisasi use case harus disesuaikan dengan arsitektur yang dikembangkan, sebaliknya arsitektur juga harus memberikan ruang untuk realisasi semua use case yang dibutuhkan, baik pada awal pengembangan hingga beberapa waktu ke depan.

\section{c. Iteration \& Incremental}

Iterasi mengacu pada tahapan-tahapan dalam workflow, sedangkan increment mengacu pada pertumbuhan produk. Proses pengembangan software melalui iterasi sekumpulan workflow yang diorganisasikan ke dalam empat fase, yaitu inception, elaboration, construction, dan transition. Setiap iterasi akan memberikan pengaruh pada kemajuan sistem.

Dalam Unified Process, project dikembangkan dalam empat fase yang berbeda. Saat project beralih dari satu fase ke fase berikutnya, jumlah kerja yang dilakukan di tiap workflow juga berubah. Gambar 1 menunjukkan hubungan antara fase dengan workflow. Bagian horizontal atas menunjukkan fase-fase yang 
harus dijalani, bagian vertikal ke bawah menunjukkan workflow, sedangkan bagian horizontal bawah menunjukkan iterasi. Kurva menunjukkan bobot kerja yang harus dilakukan pada setiap workflow dalam setiap fase. Setiap fase dapat terdiri atas satu atau beberapa iterasi workflow. Banyaknya iterasi pada setiap fase tergantung pada kompleksitas sistem yang dikembangkan [1].

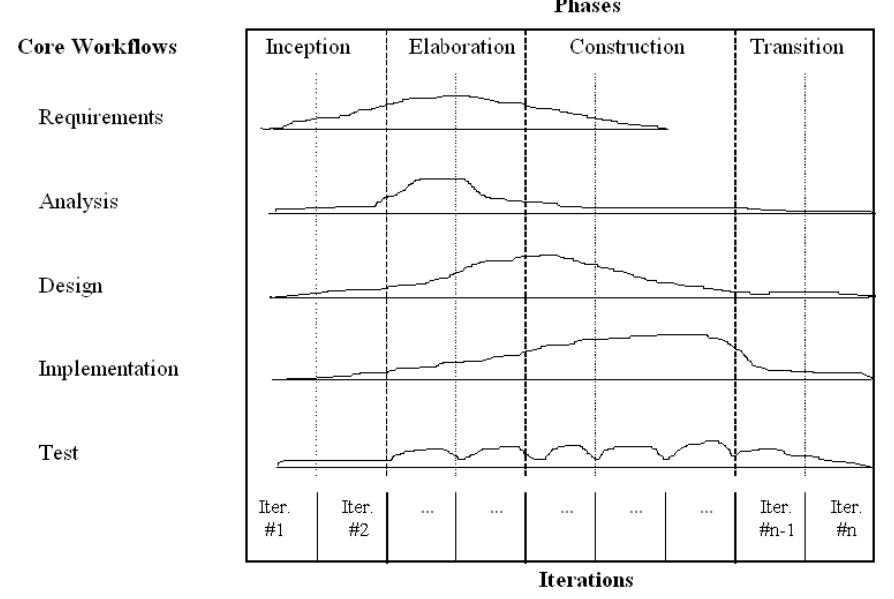

Gambar 1. Hubungan Fase dengan Workflow dalam Unified Process

Penjelasan tiap-tiap fase dalam pengembangan software adalah sebagai berikut [1]:

a. Inception

Inception mendefinisikan lingkup project dan mengembangkan business case untuk sistem. Fase ini terfokus pada requirement serta sedikit melakukan analisis dan design.

b. Elaboration

Aktivitas yang dilakukan pada fase ini adalah melengkapi requirement, baik fungsional maupun nonfungsional serta melakukan analisis dan desain. Salah satu aktivitas utama dalam fase ini adalah pembuatan arsitektur sistem. Pada fase ini, juga telah dilakukan sedikit implementasi dan pengujian untuk mengeksekusi arsitektur yang diciptakan tersebut.

c. Construction

Construction merupakan fase pembangunan sistem. Pada fase ini masih dapat dilakukan sedikit analisis untuk melengkapi hasil analisis yang telah dihasilkan pada fase sebelumnya. Tiga workflow terakhir, yaitu desain, implementasi, dan pengujian menjadi aktivitas utama dalam fase ini.

d. Transition

Transition merupakan peralihan produk ke lingkungan user (beta release). Sejumlah user akan mencoba produk yang telah dihasilkan dan melaporkan defect yang ditemukan. Fase ini berakhir pada release product. Setiap fase dapat terdiri atas satu atau beberapa iterasi workflow (requirement, analysis, design, implementation, dan test). Workflow menunjukkan urutan aktifitas yang harus dilakukan, dan aktivitas menentukan apa yang harus dilakukan dan artifak yang perlu dihasilkan [1].

\section{METODOLOGI PENELITIAN}

Penelitian yang dilakukan [2], Program Studi Komputer dan Sistem Informasi (PSKSI) adalah salah satu program studi di Universitas Gadjah Mada (UGM) yang bergerak di bidang teknologi informasi. Program Studi ini memiliki mahasiswa yang tidak sedikit, dan mempunyai mata kuliah yang juga tidak sedikit di tiap angkatannya. Tercatat hamper 50 mata kuliah yang harus terselenggara dalam satu semester. Selain matakuliah teori, terdapat juga matakuliah praktikum yang diselenggarakan di laboratorium dengan Presentase jam pelaksanaan $60 \% \mathrm{mk}$ praktikum dan $40 \% \mathrm{mk}$ teori, sehingga penyelenggaraan perkuliahan lebih banyak dilakukan di dalam laboratorium komputer. Dalam pelaksanaannya tidak hanya mahasiswa wajib yang mengambil mata kuliah tertentu, namun ada juga mahasiswa yang berniat mengulang mata kuliah tersebut, sehingga ada beberapa mahasiswa yang harus memilih jadwal yang sesuai. Peneliti membuat sistem manajemen pengelolaan dan pengolahan penjadwalan mata kuliah praktikum yang dapat membantu laboran dalam menyusun jadwal praktikum dan presensi sehingga mengurangi terjadinya 
kesalahan dalam penyusunan jadwal dan presensi yang berdampak pada kegiatan perkuliahan nantinya. Semua itu akan teratasi oleh sistem informasi berbasis komputer yaitu sistem informasi persiapan praktikum di PSKSI sekolah vokasi UGM [2]. Berbeda dengan penelitian yang dilakukan [3], Efisiensi dari pemanfaatan waktu dalam perkuliahan adalah letak pada sistem penyampian jadwal kuliah. Seringkali masih dijumpai jadwal kuliah manual yang tertulis dalam suatu media semisal kertas. Hal tersebut dirasa kurang efektif bila dikaitkan dengan kondisi yang ada dalam kegiatan perkuliahan, penyimpanan perubahan-perubahan jadwal perkuliahan dirasa merupakan hal yag belum bisa ditangani, oleh karena itu maka dibutuhkan mekanisme sistem informasi yang mampu menangani kondisi-kondisi perubahan tersebut, sehingga civitas akademika akan memperoleh segala jenis perubahan tersebut dengan cepat. Peneliti membuat sistem penjadwalan berbasis web. [3]

Sistem penjadwalan kuliah menggunakan algoritma genetika yang dibuat oleh [4], ditujukan untuk memperoleh jadwal berdasarkan data sumber seperti data mahasiswa, dosen, ruangan, mata kuliah, waktu dan data registrasi mahasiswa serta data-data batasan. Pemecahan masalah penjadwalan kuliah dapat dilakukan menggunakan algoritma genetika, setelah terlebih dahulu melakukan pendefinisian kromosom, operator-operator, dan fungsi objektif serta penentuan parameter-parameter. Hasil dari penelitian ini adalah suatu perangkat lunak untuk membantu sistem penjadwalan mata kuliah yang disesuaikan dengan waktu kehadiran dosen dapat hadir sehingga akan menghasilkan penjadwalan secara otomatis sesuai dengan bobot mata kuliah dan jam mengajar dosen pada jumlah ruangan yang terbatas maka diharapkan dapat memecahkan masalah dalam penjadwalan mata kuliah, sehingga tidak perlu menunggu waktu lama untuk menyesuaikan kondisi baik dari dosen pengajar maupun bobot mata kuliah dalam pengaturan jadwal kuliah [4]. Alokasi penjadwalan adalah proses menyusun jadwal (alokasi sumber daya pada objek-objek yang ada pada ruang waktu dan bergantung pada kendala-kendala sedemikian rupa sehingga terpenuhi sekumpulan sasaran yang diinginkan) atau urutan proses yang diperlukan dalam sebuah persoalan [5]. Dalam Penelitian yang akan dilakukan peneliti adalah melakukan analisa mengenai sistem yang sudah ada di UNISA dengan metode objek oriented yang nantinya akan digunakan sebagai dasar analisa sistem baru untuk alokasi penjadwalan menggunakan algoritma genetika dipenelitian selanjutnya. Kerangka konsep penelitian disajikan pada Gambar 2.

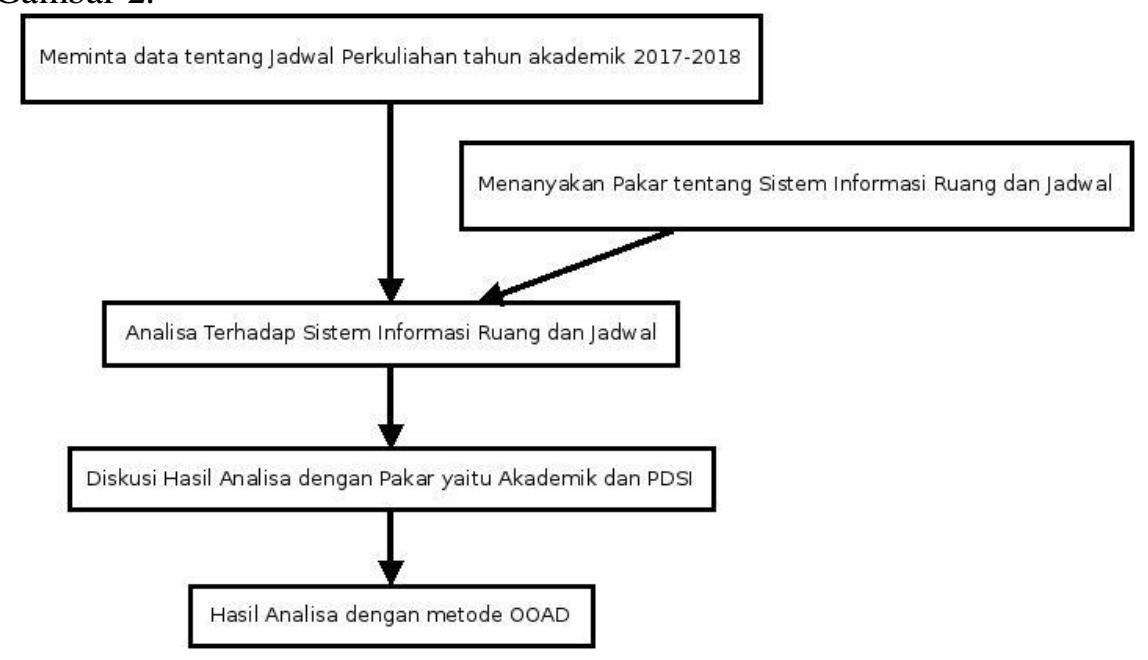

Gambar 2. Kerangka Konsep Penelitian

\section{HASIL DAN PEMBAHASAN}

\section{a. Use Case Diagram}

Use case mendeskripsikan interaksi antara aktor di dalam sistem informasi ruang dan jadwal di UNISA Yogyakarta. Use case diagram menjelaskan hubungan fungsional yang diharapkan dari perancangan sebuah sistem. Dalam hal ini yang lebih ditekankan adalah "apa" yang dapat diperbuat sistem, bukan "bagaimana". Sebuah use case menggambarkan sebuah interaksi yang terjadi antara aktor dengan sistem. Use case merupakan sebuah pekerjaan tertentu, misalnya menyusun Matakuliah dan Daftar Dosen Pengajar yang ditawarkan, Mengelola daftar matakuliah, Mengelola daftar dosen pengajar, Mengelola Daftar Ruangan, Membuat Jadwal Perkuliahan, Menyetujui jadwal Perkuliahan, Konfirmasi 
ketersediaan dosen pengajar, Menetapkan jadwal perkuliahan, Melihat jadwal perkuliahan dan Mengelola jadwal perkuliahan manual.

1) Identifikasi Aktor dijabarkan pada Tabel 1.

Tabel 1. Identifikasi Aktor

\begin{tabular}{|c|l|l|}
\hline No & \multicolumn{1}{|c|}{ Aktor } & \multicolumn{1}{c|}{ Deskripsi } \\
\hline 1 & Akademik & $\begin{array}{l}\text { Petugas Akademik yang bertugas masing-masing dalam aktivitas } \text { use case } \\
\text { sesuai job desk masing-masing }\end{array}$ \\
\hline 2 & Kaprodi & $\begin{array}{l}\text { Ketua Program Studi yang berwenang untuk menentukan team teaching } \\
\text { sesuai kepakaran dosen serta memberikan verifikasi jadwal kuliah }\end{array}$ \\
\hline 3 & Aset & Petugas Biro Aset yang melakukan maintenance ruang \\
\hline 4 & Dosen & Dosen yang mendapatkan tugas mengajar suatu mata kuliah \\
\hline 5 & Mahasiswa & Peserta kuliah yang mendaftar atau KRS \\
\hline
\end{tabular}

2) Identifikasi Diagram Use Case dijabarkan pada Tabel 2.

Tabel 2. Identifikasi Use Case

\begin{tabular}{|c|c|c|c|}
\hline No & Use Case & Deskripsi & Aktor \\
\hline 1 & $\begin{array}{l}\text { Menyusun daftar mata } \\
\text { kuliah dan dosen } \\
\text { pengajar yang } \\
\text { ditawarkan }\end{array}$ & $\begin{array}{l}\text { Melakukan pendataan matakuliah dan dosen } \\
\text { pengajar serta team teaching untuk matakuliah } \\
\text { yang ditawarkan pada semester tersebut }\end{array}$ & Kaprodi \\
\hline 2 & $\begin{array}{l}\text { Mengelola Daftar Mata } \\
\text { Kuliah }\end{array}$ & $\begin{array}{l}\text { Melakukan pengelolaan untuk daftar matakuliah } \\
\text { yang akan dilakukan pembuatan jadwal pada } \\
\text { semester tersebut }\end{array}$ & Akademik \\
\hline 3 & $\begin{array}{l}\text { Mengelola Daftar } \\
\text { Dosen Pengajar }\end{array}$ & $\begin{array}{l}\text { Melakukan pengelolaan untuk daftar dosen } \\
\text { pengajar yang akan dilakukan pembuatan jadwal } \\
\text { pada semester tersebut }\end{array}$ & Akademik \\
\hline 4 & $\begin{array}{l}\text { Mengelola Daftar } \\
\text { Ruangan }\end{array}$ & $\begin{array}{l}\text { Melakukan pengelolaan untuk daftar ruangan } \\
\text { yang akan dilakukan pembuatan jadwal pada } \\
\text { semester tersebut }\end{array}$ & $\begin{array}{l}\text { Akademik } \\
\text { dan aset }\end{array}$ \\
\hline 5 & $\begin{array}{l}\text { Membuat Jadwal } \\
\text { Perkuliahan }\end{array}$ & $\begin{array}{l}\text { Membuat jadwal perkuliahan berdasarkan } \\
\text { matakuliah yang ditawarkan, hari, jam dan } \\
\text { ruangan yang disediakan }\end{array}$ & Akademik \\
\hline 6 & $\begin{array}{l}\text { Menyetujui jadwal } \\
\text { perkuliahan }\end{array}$ & $\begin{array}{l}\text { Melakukan verifikasi jadwal sebelum diumumkan } \\
\text { kepada dosen pengajar maupun mahasiswa }\end{array}$ & $\begin{array}{l}\text { Kaprodi dan } \\
\text { Akademik }\end{array}$ \\
\hline 7 & $\begin{array}{l}\text { Konfirmasi } \\
\text { ketersediaan Dosen } \\
\text { Pengajar }\end{array}$ & $\begin{array}{l}\text { Melakukan konfirmasi terhadap dosen pengajar } \\
\text { dengan jadwal yang ditetapkan }\end{array}$ & $\begin{array}{l}\text { Dosen dan } \\
\text { Akademik }\end{array}$ \\
\hline 8 & $\begin{array}{l}\text { Menetapkan jadwal } \\
\text { kuliah }\end{array}$ & $\begin{array}{l}\text { Menetapkan jadwal yang sudah dibuat dengan } \\
\text { konfirmasi dari kaprodi dan dosen pengajar }\end{array}$ & Akademik \\
\hline 9 & $\begin{array}{l}\text { Melihat Jadwal } \\
\text { Perkuliahan }\end{array}$ & Menampilkan jadwal yang sudah ditetapkan & $\begin{array}{l}\text { Dosen dan } \\
\text { Mahasiswa }\end{array}$ \\
\hline 10 & $\begin{array}{l}\text { Mengelola jadwal } \\
\text { perkuliahan manual }\end{array}$ & $\begin{array}{l}\text { Melakukan pengelolaan jadwal perkuliahan saat } \\
\text { berjalan }\end{array}$ & Akademik \\
\hline
\end{tabular}

Dari identifikasi aktor dan usecase, maka dihasilkan usecase diagram seperti pada Gambar 3 yang menggabungkan antara aktor dan usecase. 


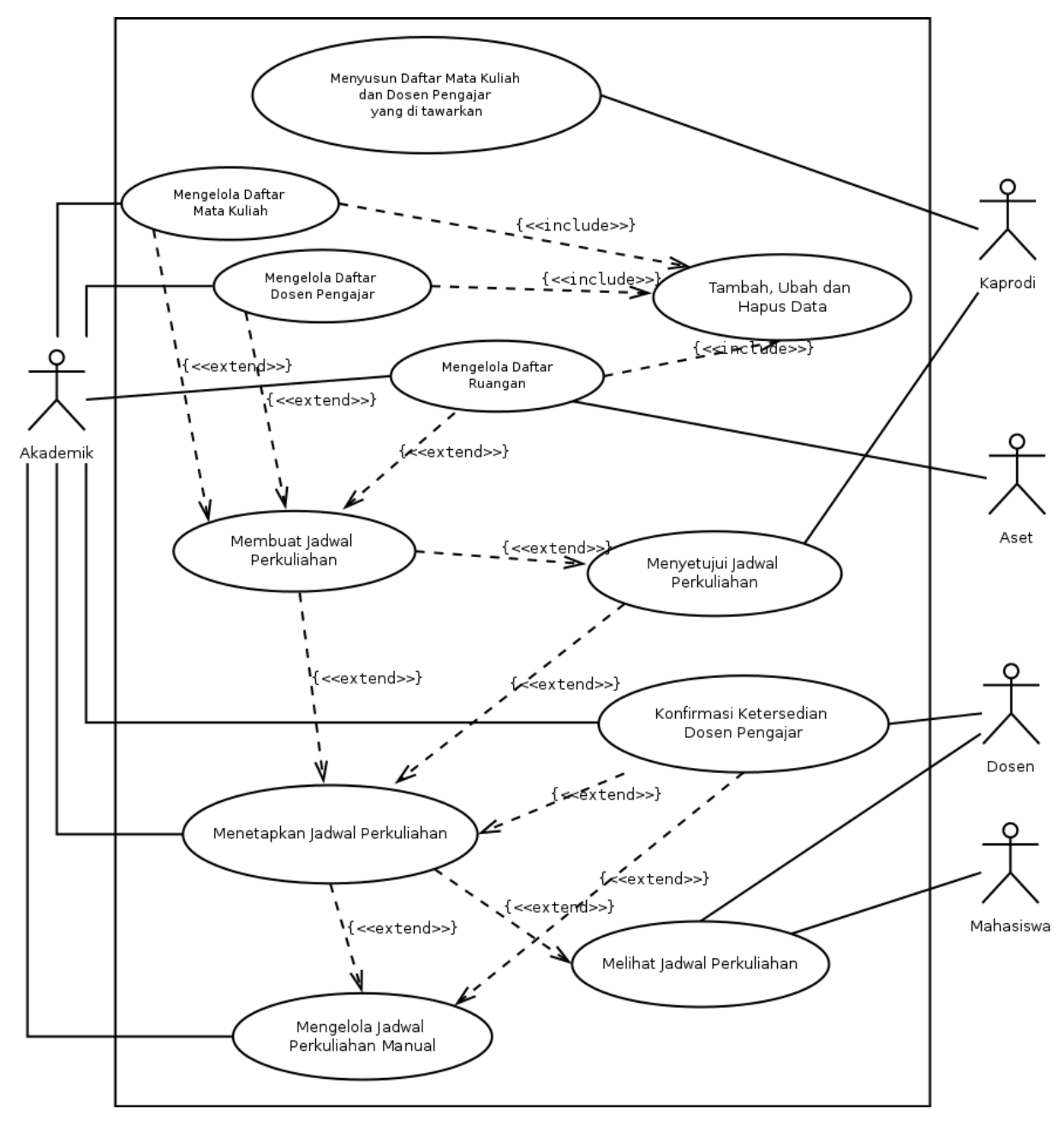

Gambar 3. Use Case Sistem Informasi Ruang dan Jadwal

\section{b. Class Diagram}

Class diagram menggambarkan kelas-kelas objek yang menyusun sebuah sistem dan juga hubungan antara kelas objek yang terjadi didalam aplikasi akademik. Class tersebut dibentuk oleh entity/object yang mempunyai atribut dan operasi. Dari class tersebut dapat terbentuk sebuah tabel yang dapat berasosiasi dengan tabel lainnya, sehingga memungkinkan terbentuknya sebuah database. Class diagram untuk Sistem Informasi Ruang dan Jadwal dapat dilihat pada Gambar 4.

\section{c. Sequence Diagram}

Sequance diagram menggambarkan interaksi antar objek di dalam dan di sekitar sistem (termasuk pengguna, display dan sebagainya) berupa message yang digambarkan terhadap waktu [6]. Sequance diagram terdiri atas dimensi vertical (waktu) dan dimensi horizontal (objek-objek yang terkait). Sequence diagram biasa digunakan untuk menggambarkan skenario atau rangkaian langkah-langkah yang dilakukan sebagai tanggapan dari sebuah event untuk menghasilkan output tertentu. Diawali dari apa yang men-trigger aktivitas tersebut, proses dan perubahan apa saja yang terjadi secara internal dan output apa yang dihasilkan. Masing-masing objek, termasuk actor, memiliki lifeline vertical. Message digambarkan sebagai garis berpanah dari satu objek ke objek lainnya. Pada fase desain berikut, message akan dipetakan menjadi operasi/metoda dari class. Activation bar menunjukkan lamanya eksekusi sebuah proses, biasanya diawali dengan diterimanya sebuah message. Untuk objek-objek yang memiliki sifat khusus, standar UML mendefinisikan icon khusus untuk objek boundary, controller dan persistent entity. Gambar 5, Gambar 6 dan Gambar 7 adalah sequence diagram dari Sistem Informasi Ruang dan Jadwal di UNISA Yogyakarta. 


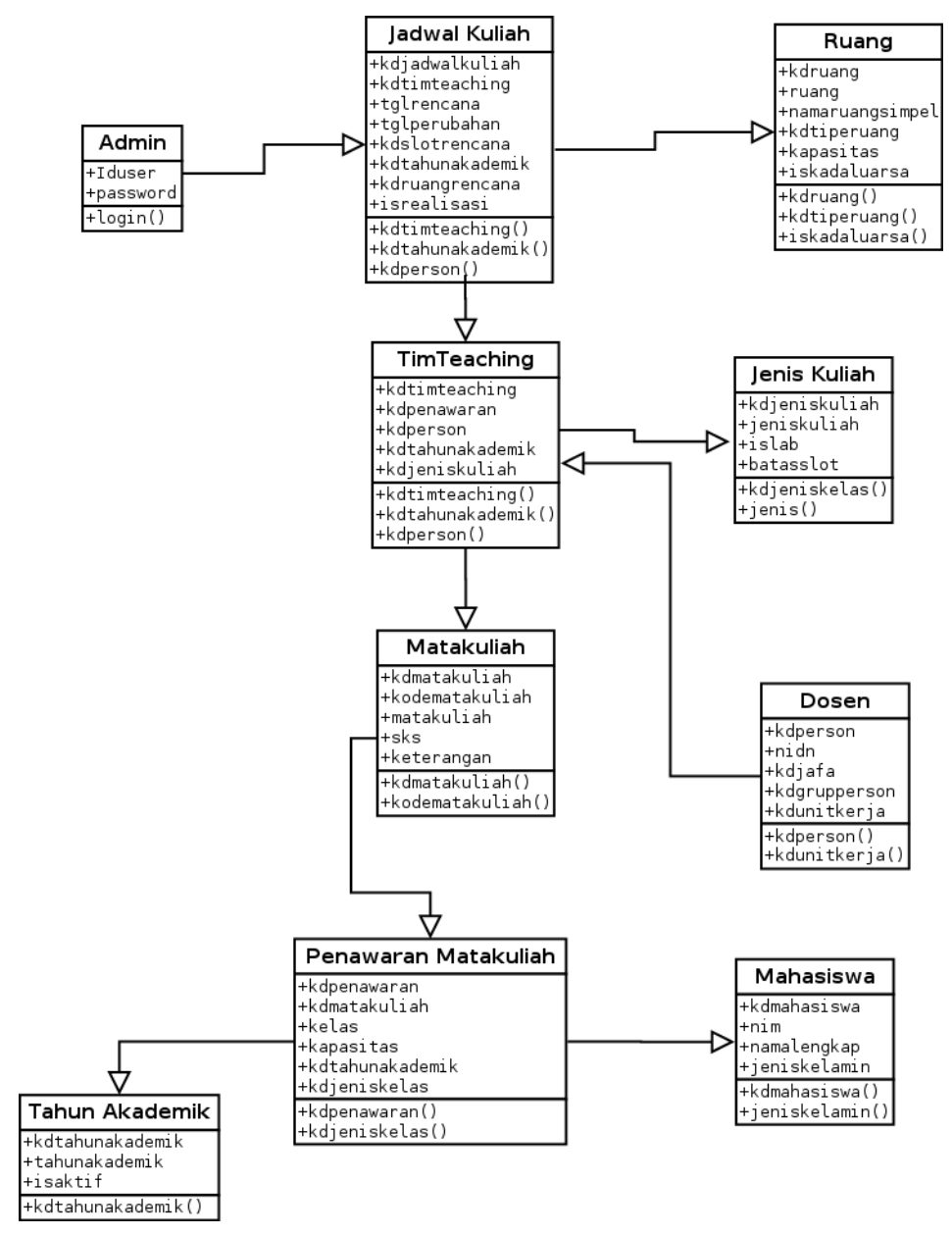

Gambar 4. Class Diagram Sistem Informasi Ruang dan Jadwal

1) Sequence Diagram Login

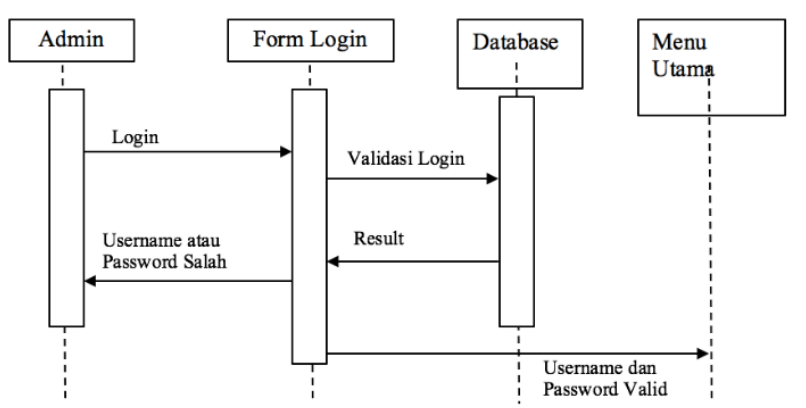

Gambar 5. Sequence Diagram Login Admin

2) Sequence Diagram Pembuatan Jadwal Perkuliahan 


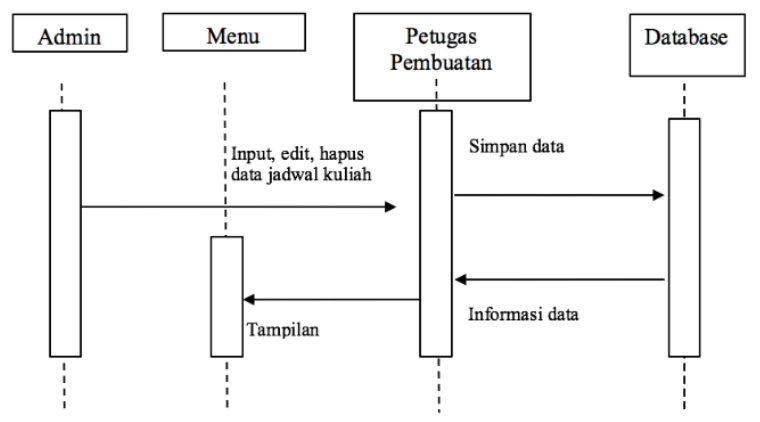

Gambar 6. Sequence Diagram Pembuatan Jadwal Kuliah

3) Sequence Diagram Form Perubahan Jadwal Perkuliahan

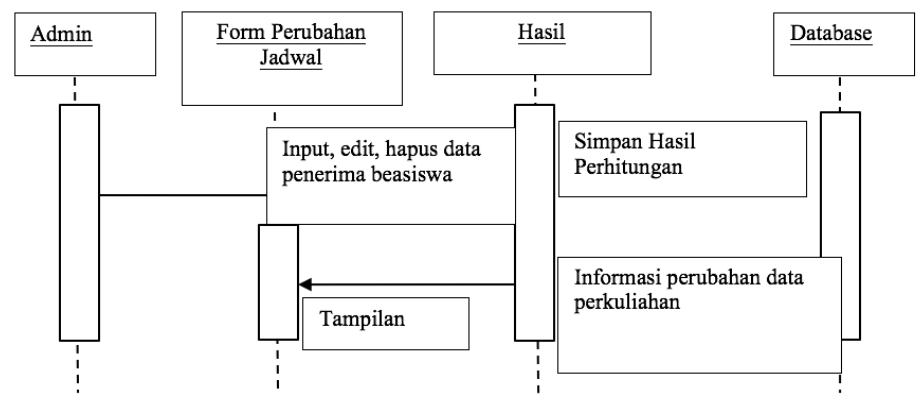

Gambar 7. Sequence Diagram Perubahan Jadwal Perkuliahan

Desain basis data yang didapatkan dari Sistem Informasi Ruang dan Jadwal seperti pada Gambar 8. Dengan 10 entitas yang terhubung dan memiliki hubungan data. 10 entitas tersebut adalah Mahasiswa, Program studi, Tahun akademik, Mata kuliah, penawaran MK, Jadwal, Dosen, Jenis kuliah, Jenis kelas dan Ruang.

\section{KESIMPULAN}

Hasil Pembahasan dan analisis dari penelitian ini adalah, pendokumentasian sistem sangat dibutuhkan untuk membuat atau mengontrol bagian mana yang dapat dilakukan pengembangan. Dengan hasil analisa sistem lama yang dihasilkan bisa dijadikan acuan untuk penelitian selanjutnya untuk melakukan desain sistem kembali untuk perbaikan. Seperti pada Sistem Informasi Ruang dan Jadwal pada use case pembuatan jadwal yang masih dilakukan manual dapat dilakukan pengembangan. Saran untuk penelitian selanjutnya adalah menentukan metode yang cocok untuk digunakan pembuatan jadwal secara otomatis. 


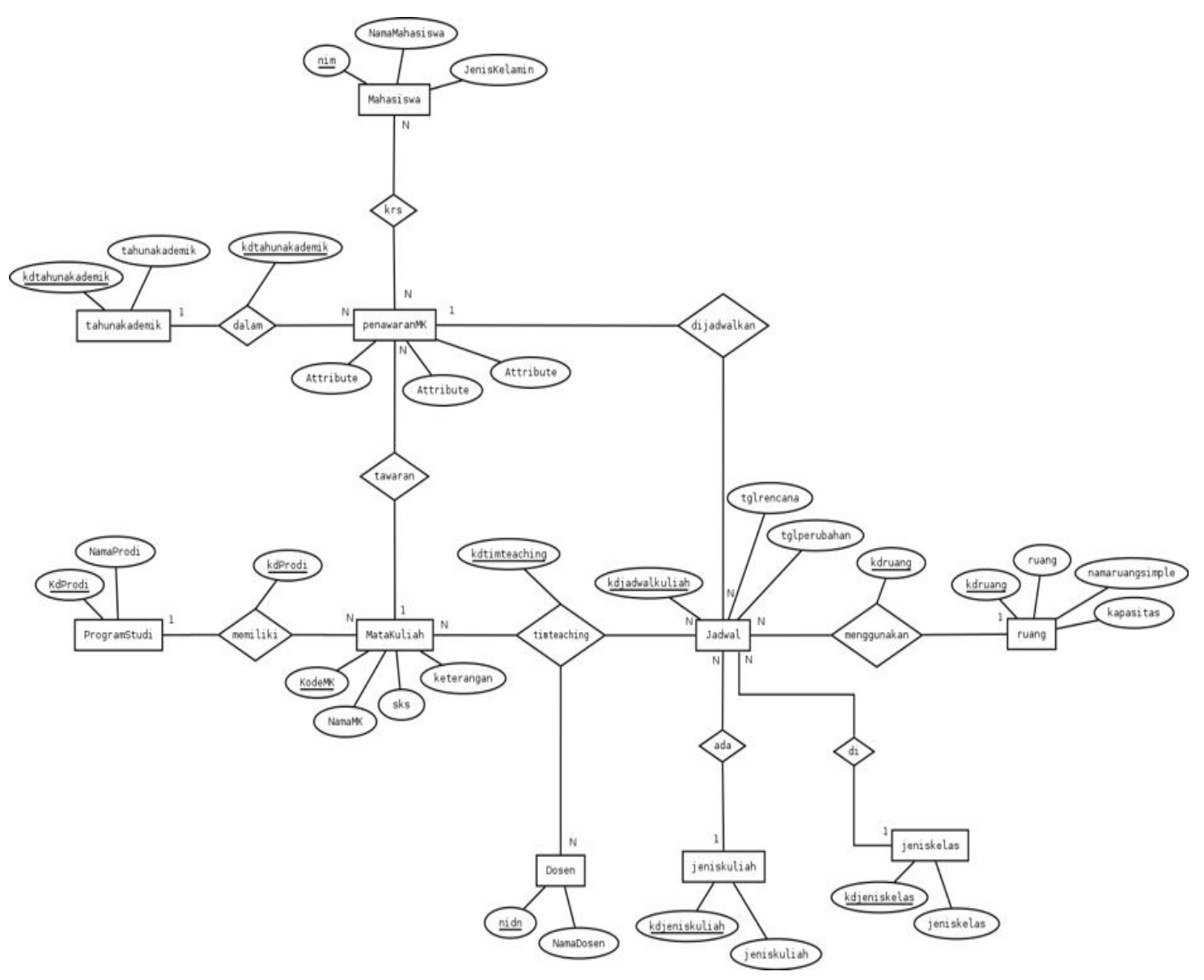

Gambar 8. Entity Relational Diagram Sistem Informasi Ruang dan Jadwal

\section{DAFTAR PUSTAKA}

[1] I. Jacobson, G. Booch, and J. Rumbaugh, "The Unified Software Development Process" United State : Addison-Wesley, 1999.

[2] A. R. Demiawansyah, "Sistem Informasi Persiapan Praktikum Di Program Studi Komputer Dan Sistem Informasi Sekolah Vokasi Universitas Gadjah Mada", Skripsi Universitas Gadjah Mada, 2014.

[3] R. Mubarok, "Sistem Informasi Jadwal Kuliah Berbasis Website" Tugas Akhir. Universitas Gadjah Mada, 2015.

[4] A. Baraja, "Pengembangan Dan Implementasi Sistem Informasi Penjadwalan Mata Kuliah Otomatis Menggunakan Metode Algoritma Genetik: Studi Di Universitas Surakarta." Tesis Universitas Gadjah Mada, 2009.

[5] D. R. Anamisa, "Implementasi Alokasi Jadwal Mata Pelajaran Smu Menggunakan Algoritma Koloni Semut (Aks)", Jurnal Ilmiah NERO, Vol. 1 No. 1 p. 33-41, 2014.

[6] J. Arlow and I. Neustadt, "Unified Process: Pratical Object-Orientied Analysis and Design.", Great Britain : Addison-Wesley, 2002. 